\title{
Why Engage with More Institutions? Changes in Economic Power Distribution and Levels of Economic Cooperation
}

\author{
In Tae Yoo
}

\begin{abstract}
What is the effect of changing economic power on the level of institutional cooperation? The existing literature provides contradictory theories. Some posit that power preponderance, such as the presence of hegemony, is the key to greater cooperation, whereas others - such as neofunctionalists - contend that power parity is a more favorable condition for deeper integration. Unlike these monotonous and static proposals, this article argues for the presence of a curvilinear and dynamic relationship between changes in power ratios and levels of formal economic integration, showing extensive cooperation at large and small power gap differences but less cooperation at the status quo. In addition, states' concern for the distributive consequences of formal economic integration is considered a key condition in the development of the integration. This power gap difference hypothesis is tested with my original data set of four-tier preferential trade agreements (PTAs) from 1950 to 2005. The analysis employs models for ordered outcomes. The research findings largely support the power gap difference hypothesis and add to our knowledge that the dynamic shift of economic power and distribution gives incentives to states to develop certain levels of formal integration.
\end{abstract}

Key Words: economic power gap differences, distributive effects, formal economic integration, preferential trade agreements

$\mathrm{E}$ conomic competitiveness and growth are essential to every state not only in terms of national wealth but also for influence in the international system. States often adopt economic integration with other states as a way to achieve these goals, and preferential trade agreements (PTAs) have been increasingly used as a major policy tool. ${ }^{1}$ For example, the European Community (EC) enlarged its membership and deepened its level of integration, accompanied by the establishment of a series of economic agreements. Behind this expansion, EC

\footnotetext{
*In Tae Yoo (iqewoup@gmail.com) is a researcher at the Institute of East and West Studies at Yonsei University. He received his Ph.D. in Political Science from the University of South Carolina. His research interests include the various dimensions of security and economic integration and the impact that they have on other issue-areas, such as militarized conflict resolution, environment and natural resource management. The author wishes to thank Harvey Starr, Lee Walker, Katherine Barbieri, and Timothy Peterson for their comments on earlier versions of this article and is also grateful to three anonymous reviewers for their constructive comments.
}

The Korean J ournal of International Studies Vol.13-2 (August 2015), 291-321. http://dx.doi.org/10.14731/kjis.2015.08.13.2.291 
states sought to develop larger and freer markets, whereas applicants were attracted to membership due to the growing economic performance gap between EC member-states and themselves. Since the late 1990s, East Asian countries also have been eager to develop a regional economic community based on PTAs, and yet the region thus far has only witnessed nascent stages of economic regionalism.

Under what conditions do states initiate formal economic integration and develop them once initiated? Scholars of international relations have discovered reasons for the signing of PTAs as policy tools for the achievement of other purposes (e.g., political, diplomatic, strategic) or investigated sources (e.g., regime type, alliance, international organization) of their variation in the features of domestic governance. However, with regard to PTA formation and development, states' concern for power - which is a problematic but central concept in the discipline - is largely ignored in the empirical literature. How structural conditions shape and affect states' preferences for PTAs warrants a thorough examination.

Defining market size as economic power, I argue that changes in economic size affect the decisions of states to pursue PTAs. ${ }^{2}$ In particular, because states are concerned about their economic power relative to others, dynamic changes in economic power between states will provide them with the conditions under which they become willing to pursue PTAs, as the economic institutions are expected to improve the economic performance of those states by facilitating economic transactions, lowering tariffs, and inviting more investments. These dynamic changes in power gap differences create incentives for states to prefer PTAs, especially because institutional features of PTAs involve long-term benefits, as well as a broader scope of cooperation, unlike such economic transactions as trade flows or financial investments.

A model of formal economic integration focusing on the autonomy-wealth trade-off will be presented. ${ }^{3}$ I then derive testable hypotheses; essentially, that

\footnotetext{
${ }^{1}$ PTAs have proliferated especially since the 1990 s so that nearly all of the World Trade Organization's (WTO) members are now parties to at least one or more agreements (Fiorentino, Verdeja and Toqueboeuf 2006).

${ }^{2}$ My theoretical argument draws on the literature of power transition theory (PTT), which focuses on the implications of power shifts on state behavior. Theoretical arguments in the present study advance on arguments of PTT by applying them to the institutional development of economic cooperation rather than to the likelihood war or the stability of alliances (Lemke 2002; Kim and Morrow 1992). Only a few empirical works have investigated the relationship between power shifts and formal economic integration. For some of these exceptional studies see Genna and Hiroi (2004) and Grieco (1997). Additionally, my argument goes further by considering the distributional effects of such integration.

3 This model of formal economic integration draws on the model of alliance behavior that focus-
} 
increasing and decreasing power gap differences are more likely to lead states to higher levels of formal economic integration. This is because smaller states will prefer to have PTAs to catch up with the growing economies of larger states, and larger states will want PTAs not only for economies of scale but also for other purposes to increase their influence on partners. In brief, the proposed hypotheses suggest a curvilinear relationship between power gap differences and levels of PTAs.

I test the hypotheses in two steps. First, the main argument is that both increasing and decreasing power gap differences will be more likely to create incentives for PTA formation and development than the status quo. To test this combined argument, I use ordered probit models for the categorical dependent variable, PTAs. This curvilinear hypothesis is puzzling, however, because two different types of changes in the economic power gap - that is, either increasing or decreasing changes - are expected to lead states to the same pattern of behavior. Thus, second, I further investigate the effect of a condition, which differentiates one of the two different types from the other. I test the hypothesis that the existence of previously-established PTAs may distinguish groups with decreasing power gap differences from those with increasing power gap differences.

Research into the effects of economic size on the development of PTAs is important for several reasons. First, the relationship between power and international cooperation is one of the fundamental questions of international relations. This paper addresses this enduring debate afresh by adding insights through the examination of the effects of certain types of power distributions - that is, economic power that is indicated by market size - on economic cooperation rather than on military conflict (Mansfield 1994). Second, the literature on institutional design has paid little attention to the structural conditions of the distribution of economic power to explain variations in international institutional design (Koremenos, Lipson and Snidal 2001, 761). This paper provides reasons why the dynamics of economic power distribution may drive a state's choice of a specific type of institution arrangement among different levels of PTAs.

Lastly, this study also seeks to add to the comparative regionalism literature concerning the configuration of various political, economic, and social factors (Büthe and Milner 2014; Finn 2010; Mansfield and Milner 1999). The present

es on the autonomy-security trade-off (Morrow 1991). Adapting Morrow's model to explaining formal economic integration, I identify both economic and other interests for economic agreements. However, the crucial difference between the two models is that, whereas the model of alliances shows alliances to be more likely to break up when the military capabilities of the allies change, my model of formal economic integration expects states to develop existing economic agreements when the gap of member states' economic capabilities decreases. 
study not only sheds light on one of the political conditions - that is, the size of the economy - but also provides answers to the puzzle as to whether power concentration or power equity among member states is conducive to regional integration (Deutsch et al. 1957; Nye 1971). Only a few studies have adopted empirical analysis in an attempt to solve the puzzle based on a broad range of cases across various regions. Thus, the present study intends to contribute to the literature by statistically testing hypotheses on the effect of structural conditions on economic regionalism.

The first section, "Why Formal Economic Integration?" reviews the existing literature on why PTAs are formed and what effect PTAs exert, and frames this by identifying two shortfalls in the literature. The next section, "Economic Power Gap Differences and Formal Economic Integration," develops theoretical arguments by highlighting the concept of economic power gap differences as a structural condition and by deriving states' incentives for forming and developing PTAs based on that structural condition. I develop two hypotheses: one about the curvilinear relationship and the other about a differentiating condition that distinguishes groups of states with decreasing power gap differences from those with increasing power gap differences. The third section, "Research Design and Data," discusses the research design and the data before proceeding to carry out the two analyses. I end the analyses with an extended discussion of the tested mechanism, focusing on European Union cases in the "Discussion" section. The concluding section summarizes the findings of this article, suggests broader implications of the results, and offers an agenda for future research.

\section{WHY FORMAL ECONOMIC INTEGRATION?}

PTAs have become the centerpiece of states' commercial policy for achieving formal economic integration with other states. Formal economic integration may be understood as the institutional framework established by various bilateral or multilateral treaties in the economic realm, whereas informal integration refers to the increase in both the volume of transactions and the frequency of interactions that may be triggered and amplified by the formal framework (Wallace 1994). Formal economic integration constitutes part of the recent surge of commercial regionalism, the latter defined as "a political process characterized by economic policy cooperation and coordination among countries," which has also been driven largely by the formation and spread of PTAs (Mansfield and Milner 1999, 591). Almost every country around the world is now a party to at least one PTA due to the proliferation of such agreements since 1990. 
Understanding PTAs in this way, scholars have analyzed the relationship between various political, economic, and social conditions motivating this particular type of economic cooperation. They have found, for example, that various governments negotiate, conclude, ratify, and implement PTAs with other governments because PTAs offer the promise of larger markets and increased investments for the participating parties. In addition to these expected economic benefits for states, scholars have ascertained many other reasons for forming PTAs. Through careful analysis of applicable factors, scholars have developed four relatively distinct levels of PTA-based integration.

At the systemic level, hegemons have intervened in order to help states form a group with legal economic ties (Grieco 1999; Crone 1993). Multilateral regimes, such as the General Agreement on Tariffs and Trade (GATT) and its successor, the WTO, have facilitated cooperation in the formation of formal economic agreements among states (Mansfield and Reinhardt 2008); on the other hand, ongoing economic conflict between countries in the North and South within the WTO has caused many states to turn to PTAs to open their markets more quickly among like-minded states. States also have wanted to enter into plurilateral agreements in order to increase bargaining power within multilateral institutions as a group of states rather than as a single state.

International diffusion mechanisms in the proliferation of PTAs have also been discussed. A domino theory of regionalism suggests that domestic exporters in countries that are excluded from an existing regional bloc become pro-membership forces pressing their governments to join the regional bloc or form a new regional grouping (Baldwin and Jaimovich 2012). PTA proliferation is also the consequence of the policy choices of governments that are influenced by the actions of their peers and/or competitors (Lee and Bai 2013; Solís, Stallings and Katada 2009; Simmons, Dobbin and Garrett 2006). In such cases, intergovernmental organizations have often been channels for the diffusion of PTA policies (Cao 2009; Bearce and Bondanella 2007; Kono 2007).

The theoretical framework of strategic issue-linkages or spill-over suggests other reasons for PTA formation. In the bargaining process, states consider the interests of both domestic socio-economic actors and international actors across diverse issue-areas (Tsebelis 1990; Putnam 1988). States also link PTAs to foreign and security policy considerations, pursuing PTAs not only for strategic or military purposes but also for the potential pacifying effects of these arrangements (Mansfield and Pevehouse 2000; Mansfield, Pevehouse and Bearce 1999). States may also sign trade agreements to facilitate cooperation in the conservation of the natural environment to manage negative externalities (Jinnah 2011; Grossman and Krueger 1993). Moreover, human rights have been the target of 
PTAs, which are used as leverage to help improve the human rights conditions of (potential) member states (Kim 2012; Hafner-Burton 2005). Additionally, PTAs often have been concluded through the use of side-payments, such as foreign aid, to assist states with trade liberalization and structural reforms (Baccini and Urpelainen 2012).

The number of states that cooperate with one another is another determinant of the institutional features of economic cooperation (Axelrod and Robert 1985; Snidal 1985; Krasner 1976). Regional economic blocs enlarge their membership because individual states want to reap the benefits of economies of scale. Increasing the number of members, however, tends to lead to congestion and crowding, so that gains from enlarged membership may be lost (Andrianmananjara 2002).

The political economy literature of formal economic integration also is concerned with the domestic conditions that drive the demand for formal economic integration. When the regional configuration of economic ideology is homogeneous, and those neighboring states form a coalition centered on internationalization and economic liberalization, states are more likely to achieve regional cooperation (Solingen 1998). Some business-related special-interest groups become strong supporters of those coalitions, and so may put pressure on incumbent governments through such actions as campaign contributions to politicians in pursuit of trade policies that those interest groups prefer (Grossman and Helpman 1995). Even though a government aggregates the preferences of those domestic social groups, it may still be able to make an autonomous decision on whether or not to join PTAs apart from those preferences (Moravcsik 1997).

Scholars of international economic cooperation have also found that various features of domestic governance have influence on the formation and development of PTAs. In general, because democracies have larger 'selectorates' who may benefit more from increased formal integration, democratic leaders are more likely to pursue PTAs - essentially 'public goods' - than autocrats, who maintain power by distributing private goods, such as rents from protectionism, but only to a smaller group of supporters (Mansfield, Milner and Pevehouse 2008). Some democracies also have more porous decision-making processes than other democracies, through which decision-making power is shared among diverse institutional and partisan actors. As the number of veto players increases due to the nature of the decision-making process, it becomes more difficult for actor preferences to converge and more likely to observe policy stasis or adherence to the status quo (Mansfield, Milner and Pevehouse 2007).

The literature has identified incentives for political leaders to negotiate PTAs for political survival. For example, political leaders may use PTAs to retain office. 
In an attempt to consolidate the democratization process, leaders could use the redistributive mechanism of PTAs to reward supporting groups, to attract new supporting groups, or to put opposing groups at a disadvantage (Milner and Kubota 2005). Moreover, political leaders recognize that signing a PTA sends a credible signal about continued domestic economic reform to foreign, as well as domestic, investors because once states enter PTAs, they will find it costly to renege on those agreements. Thus, leaders sign PTAs to increase domestic economic performance and, thus, to garner more votes for the current leaders in power.

I advance two additions to the existing literature that will lay the foundation for the arguments and analysis in this article. First, scholars have not explicitly incorporated the role of economic power, which is perceived in a relative sense, in their analysis of PTA formation and development. Explanations in the literature for why states form or join PTAs include the above conditions at the systemic, international, domestic, and individual levels, but these existing explanations do not incorporate the role that the concerns of states for economic power play in the process. If states expect benefits from prospective PTAs, they should consider costs to initiate or partake in PTAs. As in any kind of cooperative venture, who would shoulder more of the burden, or how to divide up the costs, are perennial problems in PTA formation and development. I argue that the changing distribution of economic power may provide states with significant incentives to move toward PTA formation and development.

Second, on a related note, existing scholarly works do not adequately address the distribution of gains from PTAs. As summarized above, the conventional analyses of PTAs have largely focused on the initiation phase of PTAs. However, more work should be done on the later phases of PTAs to better gauge whether states should maintain, develop, or even abandon the PTAs once they are signed. States do evaluate the results of existing PTAs and decide how to move forward based on the performance of their economies relative to others. Although there should be as many complex conditions affecting the economies in the later phases as in the initiation phase, states may blame PTAs for worsening economic performance and may not want to maintain the PTAs, let alone expand upon them. Empirical analysis of such distributive concerns that could affect the later development of PTAs has largely been ignored in the literature. To address these issues, I develop explanations for why and how states' concerns for the changing distribution of economic power, as well as for the distribution of gains from PTAs, constitute conditions for PTA formation and development. 


\section{ECONOMIC POWER GAP DIFFERENCES AND FORMAL ECONOMIC INTEGRATION}

Why do states pursue PTAs? States enter into PTAs because these agreements are expected to improve economic performance by facilitating economic transactions, lowering tariffs, and inviting more investments. Establishing PTAs, however, involves not only such benefits but also certain costs. As such, states negotiate PTAs when they perceive dynamic changes in their economic power relative to others. These dynamic changes in power gap differences create incentives for states to prefer PTAs, especially because certain institutional features of PTAs signal a longer term and broader scope of cooperation than do economic transactions such as the flow of trade or financial investments.

Formal economic integration serves as a substitute for internal sources of economic growth. Economic growth promotes economic strength, which can become the foundation for power. As Thomas Hobbes states, "Wealth is power and power is wealth" (Viner 1948, 15). Therefore, states aim to increase national wealth as well as power in an anarchical international system because the economic size of a state is often identified with national power and thus a major source of influence. 4

The economic size of a state provides economic capabilities and can be the foundation for the state's ability to coerce as well as to cooperate in economic relations. Large market size offers plenteous resources for a country to mobilize for institutionalizing international commerce and provides favorable environments for growth, as well as for the state's partners to reap rich economic gains from economic interactions. In addition, a state's capacity to consume goods that are produced in other states constitutes economic power because the benefits of the other states depend upon exports to the large market of the importer state. A state with a large market will thus be able to attract more wealth from other states, as well as to wield greater influence when shaping a preferable type of cooperative arrangement based on its economic power.

In addition to the distribution of economic capabilities, what crucially matters is the distribution of benefits from cooperation. States' preferences for absolute or relative gains are not fixed but conditional (Powell 1991). Depending upon pre-

\footnotetext{
4 The theoretical conceptualization of economic power favored here is closest to "structural power," compared to other concepts of power such as decisional, conversion-process, and locational. These other types of power are not irrelevant but are less related to my theoretical discussion in producing the output of interest (Caporaso and Haggard 1989). Economic power is well represented by market size.
} 
existing relationships, a state will pursue one type of gain over the other when it comes to either forming or joining a PTA, or developing an existing PTA. If states are bound by mechanisms of iterative interactions, they tend to cooperate based on absolute gains (Axelrod and Keohane 1985). Formal economic integration generally offers environments for the development of those mechanisms, with such an institutional framework being established by various international treaties.

Formal economic integration comprises many types of PTAs, to include partial scope agreements (PSAs), free trade agreements (FTAs), customs unions (CUs), common markets (CMs), and economic unions (ECUNs) (De Melo and Panagariya 1995; Balassa 1961). These economic arrangements vary along a number of institutional dimensions. The key difference between these arrangements is the degree of trade liberalization and, therefore, the scope of policy harmonization and, ultimately, the level of integration. PSAs and FTAs eliminate trade barriers among members, but FTAs encompass a much wider scope of economic activity. In addition to the scope of FTAs, CUs establish a common external tariff, which calls for more policy coordination among members. Moreover, CMs not only liberalize trade but also facilitate the movement of factors of production among participants. ECUNs involve the establishment of a supranational authority to coordinate fiscal and monetary policies among participants. Key differences between the different levels are the degrees of economic liberalization and the extensiveness of institutionalization that each type of PTA would entail. In general, the higher the level of PTA, the broader the scope of economic activity managed by institutions and thus the deeper is the expected integration.

It should be noted that PTAs as international institutions of credible commitment have political attributes and implications that are different from mere trade transactions. The establishment and development of such institutions involve national leaders who sign international agreements, though "few of the usual transaction data directly concern high politics at the governmental elite level," and trade flow data in itself "do not serve for describing the degree of institutionalization achieved between two states" (Russett 1974, 334). Also, since PTAs involve greater political as well as economic commitment than do mere economic transactions, it will be more costly to abrogate such agreements (Morrow 1999). Therefore, states entering into or continuing a PTA signal credible commitments to cooperate, and this exerts a binding effect (Stein 2003; North 1991) such that all signatories may be able to expect long-term and broad-scope benefits from the agreements.

By way of forming such PTAs, states commonly aim to increase their influence as well as to reduce the fears or concerns of member states. As the level of formal 
economic integration rises, stronger states will have more influence on economic affairs through common fiscal and monetary policies, social affairs by raising labor rights and environmental regulations, and even security affairs by controlling military-related goods and technologies of partners due primarily to a closely coordinated institutional framework. A stronger state also may form PTAs with neighboring states to ensure a stable regional environment for its economic development, expecting to see an increase in information, transparency, and predictability from enhanced interactions and, additionally, to preempt the collapse of neighboring economies and thus prevent the spread of an economic crisis back to that home state.

Yet, states still have concerns about being members of PTAs. Upon forming or joining a PTA, a state will have to surrender a certain degree of sovereignty by delegating some aspect of decision-making to intergovernmental or supranational entities established among the members to enforce the PTA. States may also experience unequal economic growth resulting from a large gap in gains, may suffer from domestic economic restructuring, or may even experience economic absorption once integrated (Myrdal 1957).

A stronger or larger state, however, is less likely to suffer from such fears and instead is more likely to seek benefits expected from establishing institutional frameworks of formal economic integration. States with larger market size normally have more economic capacities, such as institutional, industry sectoral, infrastructural, technocratic, and human capital supports to provide for establishing common institutions. Thus, larger states will have more bargaining power to shape the institutions of economic integration to their liking. In addition, stronger states will be likely to be the focal points for institutional coordination, so they will lose less than weaker states when adjusting socio-economic systems for integration (Ikenberry 2001; Mattli 1999). Therefore, as the power gap widens between stronger states and potential partners, stronger states will gain increased economic capacities, thus bolstering incentives to establish formal economic integration.

On the other hand, smaller states also seek formal agreements of economic integration despite growing differences in power. Despite fears that smaller states could lose more of their sovereignty than larger states, smaller states might expect to gain more benefits from institutionally linking their economies to the growing economies of stronger states than they would otherwise have gained in the absence of such linkages. A weaker state is more likely to see opportunities when the economy of a stronger state keeps rapidly growing. Also, the weaker state is less likely to fear any ulterior motives of the stronger state because the weaker state will view the goals and intentions of the stronger state as economically ben- 
eficial rather than militarily threatening, expecting that the stronger state will also want a peaceful international environment in order to focus on the continuation of economic growth. 5 Thus, when the weaker state sees more opportunities than threats in a rising economy, that government will prefer economic engagement through institutions. This is captured in Hypothesis 1:

Hypothesis 1: The larger the power gap that states experience, the more likely states will form a higher level of PTA.

Even if the power gap differences decrease, a larger state may still prefer to form a PTA in order to render markets more efficient through further economic liberalization, thus boosting its own economy. A smaller state will also agree to form a PTA in order to catch up more swiftly with the larger economy. One might think that a smaller yet relatively growing state may not need to forge a PTA with a larger yet relatively shrinking economy because the economy of the smaller state is already performing relatively well without the PTA. If, however, the economic performance of the smaller state has been improving due to a preexisting positive interdependence, the smaller state will likely prefer to deepen the existing level of interdependence through the implementation of a PTA. In addition, since the economically smaller state has been growing successfully due to a preexisting positive interdependence, it is relatively free from concern about the stronger state's intentions of deepening the interdependence between them as being pernicious.

On the other hand, without a preexisting interdependence, a larger state may not desire to deepen economic integration with its partner given the differences in gains from which both countries benefit. If, however, there has been a significant, positive, and preexisting interdependence between the two countries, the larger state would focus more on absolute gains from economic transactions and expect to acquire its influence in other issues-areas in exchange for a relatively minimal economic loss. Hypothesis 2 states:

Hypothesis 2: The more states experience a reduction in the power gap, the more likely states will have a higher level of PTA.

Unlike in the case where power gap differences are increasing, however, there

\footnotetext{
${ }^{5}$ For example, China as a rising power has been relatively successful in presenting opportunities rather than threats to neighboring countries, as is observed by the absence of South Korean actions to balance against a rising China (Kang 2009).
} 
is an important modifying condition to situations in which power gap differences are decreasing. Once strong and weak states enter into an agreement, the distribution of gains becomes more important for the maintenance, and especially for the development, of the preexisting agreement than it does in the initiation stage. This is understandable, of course, for without the improvement of benefits from economic integration, a weaker state would not want to increase the degree of integration. If a weaker state had experienced an increasing power gap difference with its partner after steps towards integration, the weaker state might even attempt to renege on the existing agreement.

If, on the other hand, a weaker state has experienced economic improvements relative to its partner, the weaker state will be more likely to seek to deepen, or at least to maintain, the present level of integration. Despite the relative decreasing power gap between itself and the weaker state, the stronger state will also prefer to sustain the existing level of integration and even attempt to augment gains by agreeing to increase the level of economic liberalization and institutionalization. This is in part because, once these institutions and interests of related societal actors in the stronger state are entrenched, it will become more difficult to return to lower levels of institutionalization (Stone, Sweet and Sandholtz 1997). More importantly, though, stronger states will want to continue integration because the preferences of member states will likely be inclined toward absolute gains due to the extended time horizon and scope of cooperation - and thus they will fear less the possibility of defection from member states. The distribution of wealth therefore becomes more important in the dynamics after the creation of institutional arrangements of formal economic integration. Hypothesis 3 states:

Hypothesis 3: The more states experience an increasing power gap difference within existing PTAs, the less likely they will be to maintain or enhance those agreements.

In some situations, states are not particularly motivated to form PTAs. Especially, when the power gap difference stays the same, there is less incentive for states to establish a PTA. When both states are economically growing and both economies are performing well, they may not need to establish or develop additional economic institutional mechanisms. Also, when two states are faring badly economically, neither country will be motivated to associate its economy with the other, depressed economy.

In sum, the above three hypotheses are interrelated, constituting a curvilinear relationship between the level of cooperative institutionalization and power gap differences (see Figure 1). In other words, an increasing power gap difference 
(after point $\tau$ in Figure 1) between states increases the likelihood of the establishment of formal economic integration (Hypothesis 1). At the same time, the decreasing power gap difference between states (before point $\tau$ in Figure 1) will more likely lead to a higher level of cooperation (Hypothesis 2). There is, though, another important condition that distinguishes the left side from the right side of the parabola in Figure 1. If there is a preexisting economic interdependence among states, those experiencing a reduced power gap difference are more likely to sign a higher-level PTA. This present study hypothesizes that an existing PTA will involve preexisting interdependence. States are less likely to take an existing PTA to a higher level if those countries experience an increase in the power gap difference (Hypothesis 3).

Figure 1. Power Gap Difference (PGD) and Formal Economic Integration (FEI)

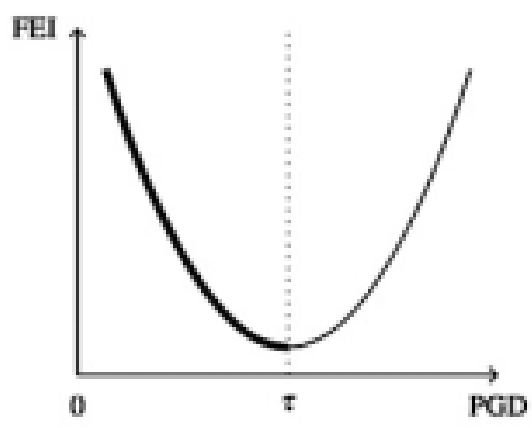

\section{RESEARCH DESIGN AND DATA}

The data set covers the list of states in the Correlates of War Project beginning in 1950. The sample is constructed from the WTO, the Global Preferential Trade Agreements Database compiled by the World Bank-Tuck Center for International Business, the Organization of American States Foreign Trade Information System and various governmental websites. ${ }^{6}$ Some types of trade agreements were excluded from the sample for three reasons. First, agreements involving quasi-state actors, such as Hong Kong and the Palestine Liberation Organization, were excluded because the theory mainly pertains to state-to-state relations.

\footnotetext{
${ }^{6}$ Some PTAs were not reported to the GATT or WTO, thus the author brought in other sources to complete the population of PTAs.
} 
Second, nonreciprocal agreements were not included as these should be considered in light of different political mechanisms rather than economic power differences. 7 Third, the sample is truncated to the right by the availability of data on the major independent variables under study.

The unit of analysis is the dyad year. The unit of observation in the data set is the PTA level at which two states sign a PTA to form a formal institutional arrangement of economic integration. Based on the theoretical and empirical conventions regarding the measurement of PTAs (Balassa 1961; Mansfield and Milner 2012), PTAs are grouped into four categories: partial scope arrangements (PSA), free trade agreements (FTA), customs unions (CU), and common markets plus economic union (CMplusECUN).

The main explanatory variables are indicators that capture the economic power gap difference and its interaction with preceding agreements between states. Since the unit of analysis is the nondirectional dyad-year, the economic power $\operatorname{gap}(\mathrm{PG})$ is $\mathrm{PG}_{i j}=\frac{\max \left[\left(G D P_{i}, G D P_{j}\right)\right]}{\left(G D P_{i}+G D P_{j}\right)}$. Gross domestic product (GDP) is regarded as the simplest and most representative indicator of economic power as it reflects the total size of each state's economy. ${ }^{8}$ As such, the economic power gap difference (PGD) is $\triangle P G_{t}(i j)=\log \left(P G_{(i j)}\right)-\log \left(P G_{t-1}(i j)\right)$. Since I hypothesize the Ushaped curvilinear curve for the relationship between PGD and the levels of PTAs, my model includes the squared term of PGD (PGD(squared)). The GDP data is from the Penn World Table version 8.o (Feenstra, Inklaar and Timmer 2013).

In addition to these main variables, PTA formations are modeled as a function of three groups of factors. The first group of factors is made up of political variables that may facilitate or hinder the formation of PTAs. Scholars have found that democracies are in general more likely to sign any type of integration agreement (Mansfield and Milner 2012). The lower democracy score between the dyad is assumed to capture the effect of domestic regime type (Regime type) (Marshall and Jaggers 2009; Dixon 1993).9 Joint membership in intergovern-

\footnotetext{
${ }^{7}$ Nonreciprocal preferential trade agreements often invoke the General System of Preferences, which are a GATT/WTO-approved violation of the MFN principle. These agreements include, for example, the African Growth and Opportunity Act, the Caribbean Basin Initiative, and the Andean Trade Preference Act.

${ }^{8}$ How to measure power is a longstanding source of controversy among scholars of international relations. Merritt and Zinnes (1989) show the overlap of various measures and that market size is a common component across those diverse alternatives.

9 This study is agnostic as to the exact features of domestic governance exerting influence on outcomes. Accordingly, I do not disaggregate domestic regime types into the effect of such factors as veto players, winning coalitions, or the judicial system (Bueno de Mesquita et al. 2005; Cheibub, Gandhi and Vreeland 2010; Przeworski 1991). However, for this present study's purposes, it is the total effect
} 
mental organizations (JointIGOs) also contributes to states forming and developing PTAs (Mansfield and Reinhardt 2008). This study is also agnostic as to the exact features of IGOs that facilitate cooperation among member states. ${ }^{10}$ Accordingly, the total number of joint dyadic memberships in IGOs for each dyad is included (Pevehouse and Nordstrom 2004). In addition, the initiation and development of PTAs may not be in favor of international conflicts between member states (Mansfield and Pevehouse 2000). Data of these conflicts (MIDs) are from the Militarized Interstate Dispute data collection compiled by the Correlates of War (COW) Project (Ghosn and Bennett 2003). Lastly, the number of members in a given PTA (MemberN) is included (Koremenos, Lipson and Snidal 2001).

The second group consists of economic variables. Trade openness is measured as the sum of both exports and imports divided by the GDPs of the dyad. The Penn World Table version 8.o (Feenstra, Inklaar and Timmer 2013) is used for the trade flow data. The logged distance between capital cities of countries is also included. The data is from the Correlates of War.

The last group consists of factors that account for trends over time and space that affect the environment within which states decide whether or not to form PTAs. To account for any time-dependent effects, I include agreement-duration years and their squares and cubes in the models (Carter and Signorino 2010). ${ }^{11}$ Similarly, states' participation in PTAs may be influenced by their neighboring countries through a diffusion process (Solís, Stallings and Katada 2009; Simmons and Elkins 2004). Accordingly, I operationalize a variable, which accounts for the number of PTAs present in certain regions as defined in the World Bank Development Indicators. ${ }^{12}$

of democratic institutions, from constraints on the executive to free elections to the role of civil rights. To be sure, I verify that the findings are fully robust with respect to alternative conceptualizations of democracy and examine the effect of credible commitment structures among democratic developing countries.

${ }^{10}$ For instance, Cao (2009) identifies at least three mechanisms: policy coercion, policy learning, and policy emulation.

${ }^{11}$ My findings are also fully robust to the models that I estimate with cubic splines suggested by Beck, Katz and Tucker (1998).

12 To be sure, a similar set of robustness checks is performed, including a spatial lag term of the dependent variable, weighted by the distance between the capital cities of states, based a spatio-temporal probit model (Neumayer and Plümper 2010; Franzese and Hays 2007). 


\section{STATISICAL MODELS AND RESULTS}

I use ordered probit analysis for all models presented, clustering standard errors on the dyad to account for non-independence by country pairs. Furthermore, I lag independent variables by one year to mitigate simultaneity bias (Hegre, Oneal and Russett 2010). Finally, models are corrected for duration dependence by including the lagged dependent variables for each of the four categories of PTAs. All models are estimated using Stata version 11.

The hypothesized relationship is modeled using a quadratic function (a parabola, with the squared term). The dependent variable $\mathrm{PTA}_{i j, t}$ is whichever one of the four tiers of PTAs is signed and maintained between states $i$ and $j$ at time $t$, consisting of PSA, FTA, CU, and CMplusECUN. If a pair of countries does not have a signed PTA, the dependent variable takes the value of o for the dyad year. If there are multiple PTAs of different levels in a given year, the dependent variable equals one of highest. For example, if a small group of states signed PTAs at the level of customs union, but the same group signed a lower level of PTAs in the process of expanding its membership in a given year, then the value is 3 .

Table 1 summarizes the results of the ordered probit models that account for the levels of formal economic integration. ${ }^{13}$ Models 1 and 4 include samples covering the time span from 1950 to 2001. ${ }^{14}$ Model 3 subsets the sample and includes only certain regions. ${ }^{15}$ The sign and significance of coefficients remain largely the same. The pattern of results is very similar across all of the models.

\footnotetext{
${ }^{13}$ Post-estimation analyses support the robustness of the specification. First, the statistical significance that the Hausman test demonstrates allows me to reject the null hypothesis that regression and ordered probit models are the same (Hausman 1978). The likelihood-ratio test also demonstrates the same result. These results support the use of the ordered probit model.

${ }^{14}$ In robustness checks, I ran different specifications with slightly different time spans. The results largely remain the same. It is almost customary to run random-effects and fixed-effects models with time-series -cross-section data. However, random-effects models are not appropriate for this study's research purposes. A fixed-effects ordered probit model is neither easily available nor recommended.

${ }^{15}$ Regional categories defined by the World Bank were used. This choice was made in order to generate the spatially lagged dependent variable in Model 3.
} 
ำ

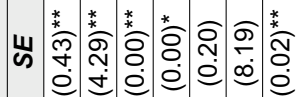

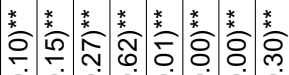

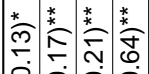

¿ $\dot{\theta} \dot{\theta} \dot{e}$

อे巳

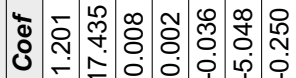

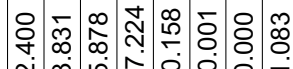

బิ

iे

山岁

N $=\dot{0} \dot{0} \infty \dot{0}$

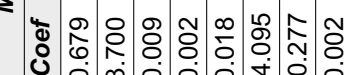

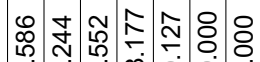

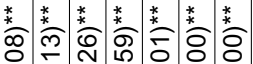

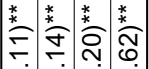

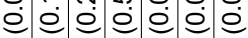

¿ ¿ ¿

Nंن̛

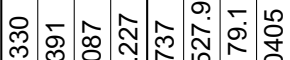

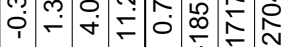

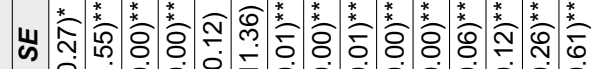

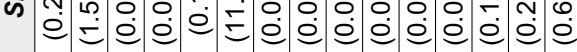

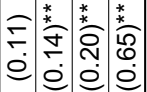

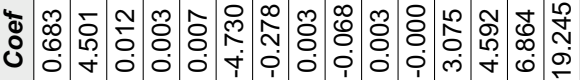

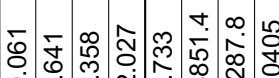

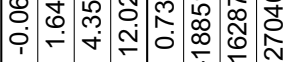

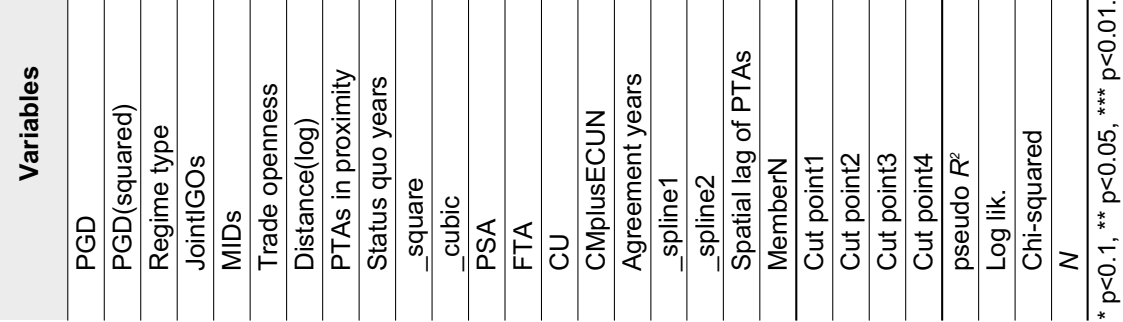


Overall, as expected by the curvilinear hypothesis, PGD(squared) is statistically significant for explaining the level of formal economic integration. States are more likely to form a higher-tiered PTA when the power gap difference between the states is either increasing or decreasing. The variable Regime type shows that states with more democratic regimes are more likely to form higher-level PTAs than those with less democratic political systems. The statistical significance of JointIGOs indicates that intergovernmental organizations are conducive to higher levels of formal economic integration. In other words, states having more joint memberships in IGOs are more likely to have higher-level PTAs. The number of members in PTAs is also significant in Model 4. The variable MemberN substantively means that the increasing number of members is associated with higher-level PTAs. Lastly, the results show that the tendency of states to form PTAs is not statistically significantly associated with interstate conflicts. ${ }^{16}$

Trade openness does not demonstrate statistical significance. This is in part because the dummy variables of the dependent variable — such as PSA, FTA, CU, and CMplusECUN - explain much of what Trade openness could account for. Substantively speaking, the lack of statistical significance of Trade openness can mean that many countries enter PTAs for purposes other than those that are economic, such as political or security concerns. Developing countries form PTAs among themselves in order to promote trade among member states, as well as to increase political solidarity despite a significant degree of trade dependence on developed countries. Distance(log) is associated with the reluctance of states to form higher-level PTAs as predicted in the gravity model.

The spatial variables, PTAs in proximity and Spatial lag of PTAs, point to the diffusion of PTAs as a pattern of a state's behavior. ${ }^{17}$ PTAs that are signed with other countries in geographic proximity are likely to lead to more PTAs. These two variables demonstrate the significant presence of a diffusion mechanism in the pattern of state behavior regarding PTAs. On the other hand, the significantly negative sign of the year variables, such as Status quo years and Agreement years in the models, suggests some duration dependence. These time variables

16 This does not necessarily refute the peace-inducing effects of PTAs, especially when they involve high volumes of trade transactions. It could rather mean that states might form PTAs as part of the reconciliation of a dispute. Additionally, states may not hesitate to pursue a war because, when they are in lower levels of PTAs, they would not have much to suffer from less economic interdependence with the conflict state. See Pollins (1989) for a discussion of dyads that often engage in actions of conflict and cooperation at the same time.

17 The spatial lag term of the dependent variable is weighted by the distance between capital cities of countries, whereas the other variable counts the number of PTAs in a certain region in a given year defined by the World Bank. 
mean that the longer member states maintain a PTA, the more likely they are to develop existing agreements. In other words, states will more likely develop their PTAs in the direction of more integration as they successfully manage their current PTAs over a longer time span based on the accumulation of experience cooperating.

For a substantive interpretation of the coefficient estimates, I generate the predicted probabilities of the four levels of PTAs. Figure 2 plots the predicted probabilities of each level of PTAs for the power gap difference based on Model 3. Figure 2 shows that the effect of the power difference gap is curvilinear. All of the lines rise at the end of both sides, showing low predicted probabilities of having a certain level of PTAs at 0 , which indicates no change in the power gap difference. Thus, states are more likely to form and maintain PTAs when their power gap differences are either decreasing or increasing.

Figure 2. The Power Gap Difference and Predicted Probabilities of PTA in Different Levels with $95 \%$ Confidence Bounds (from Model 1)
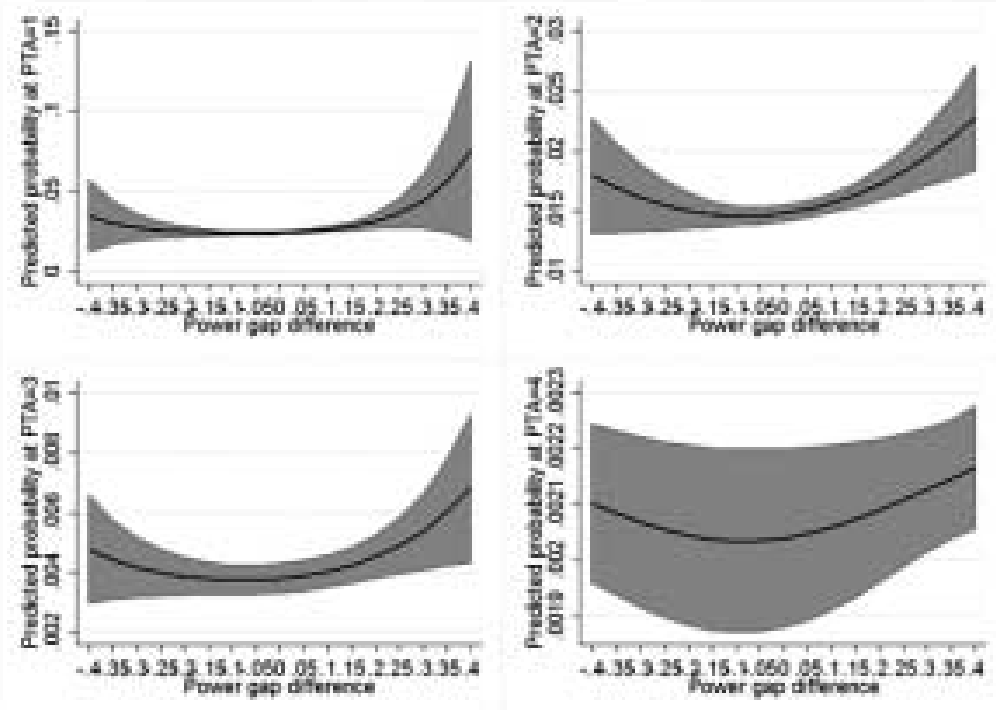

To test Hypothesis 3, I add to the above models one more variable, Distributive PTAs. This variable is generated in order to capture a conditional effect on the left side of the parabola in Figure $1 .{ }^{18}$ To generate the variable, I created a composite of three variables; two binary terms and one continuous. ${ }^{19}$ One binary term captures whether or not there is an existing PTA. The other binary 
term captures whether or not a dyad is on the left side. The continuous variable is the power gap difference PGD.

Table 2 illustrates the results of the analyses. Because the results of other variables remain largely the same, the discussion here focuses on the new variable, Distributive PTAs. In relation to Hypothesis 3, the statistical significance of this variable in Models 5 and 6 suggests that states that experience the growing power gap difference between memberships of the same PTAs are associated with their future behavior on the existing PTAs.

Table 2. The Power Gap Difference in Agreements and Level of PTAs with Distributive PTAs The Power Gap Difference in Agreements and Level of PTAs

\begin{tabular}{|c|c|c|c|c|}
\hline \multirow{2}{*}{ Variables } & \multicolumn{2}{|c|}{ Model 5} & \multicolumn{2}{|c|}{ Model 6} \\
\hline & Coef & SE & Coef & SE \\
\hline PGD & 1.020 & $(0.38)^{* * *}$ & 0.951 & $(0.39)^{* *}$ \\
\hline PGD(squared) & 3.754 & $(1.63)^{* *}$ & 2.915 & $(1.70)^{*}$ \\
\hline Distributive PTAs & -1.042 & $(0.45)^{* *}$ & -0.863 & $(0.43)^{* *}$ \\
\hline Regime type & 0.012 & $(0.00)^{\star * *}$ & 0.009 & $(0.00)^{* * *}$ \\
\hline JointIGOs & 0.003 & $(0.00)^{* * *}$ & 0.002 & $(0.00)^{* * *}$ \\
\hline Trade openness & -7.614 & $(10.55)$ & -6.601 & $(7.88)$ \\
\hline MIDs & -0.035 & $(0.13)$ & -0.023 & $(0.13)$ \\
\hline PTAs in proximity & 0.001 & $(0.00)^{* * *}$ & 0.001 & $(0.00)^{\star * *}$ \\
\hline MemberN & 0.018 & $(0.00)^{* * *}$ & 0.018 & $(0.00)^{* * *}$ \\
\hline Distance(log) & -0.304 & $(0.01)^{* * *}$ & -0.302 & $(0.01)^{* * *}$ \\
\hline Status quo years & -0.063 & $(0.01)^{\star * *}$ & & \\
\hline _square & 0.003 & $(0.00)^{* * *}$ & & \\
\hline _cubic & -0.000 & $(0.00)^{* * *}$ & & \\
\hline PSA & 2.609 & $(0.10)^{\star * *}$ & 2.116 & $(0.11)^{* * *}$ \\
\hline FTA & 4.484 & $(0.13)^{\star \star \star}$ & 4.117 & $(0.13)^{\star \star \star}$ \\
\hline $\mathrm{CU}$ & 6.731 & $(0.26)^{* * *}$ & 6.401 & $(0.26)^{\star * *}$ \\
\hline CMplusECUN & 18.619 & $(0.61)^{* * *}$ & 17.612 & $(0.59)^{\star * *}$ \\
\hline Agreement years & & & -0.122 & $(0.01)^{* * *}$ \\
\hline _spline1 & & & -0.000 & $(0.00)^{* * *}$ \\
\hline _spline2 & & & 0.000 & $(0.00)^{* * *}$ \\
\hline Cut point 1 & -0.235 & $(0.12)^{*}$ & -0.531 & $(0.12)^{* * *}$ \\
\hline Cut point 2 & 1.492 & $(0.15)^{* * *}$ & 1.213 & $(0.15)^{* * *}$ \\
\hline Cut point 3 & 4.187 & $(0.21)^{* * *}$ & 3.888 & $(0.20)^{\star * *}$ \\
\hline Cut point 4 & 11.499 & $(0.65)^{\star * *}$ & 10.653 & $(0.62)^{\star \star *}$ \\
\hline pseudo $R^{2}$ & 0.735 & & 0.740 & \\
\hline Log lik. & -18648.2 & & -18320.0 & \\
\hline Chi-squared & 16270.7 & & 15827.5 & \\
\hline$N$ & 270405 & & 270405 & \\
\hline
\end{tabular}

${ }^{*} p<0.1,{ }^{* *} p<0.05,{ }^{* * *} p<0.01$. Ordered probit estimates on state's likelihood of having PTAs. Standard errors are adjusted for clustering on dyads. 
To discuss the substantive effect of the newly generated variable, predicted probabilities at each level of PTAs are calculated and their values plotted in Figure 3. All of the predicted probabilities are statistically significant and suggest both increasing and decreasing trends over the values of Distributive PTAs at all levels of PTAs, while holding other continuous variables at their mean and binary variables at their medians. Therefore, the analysis finds support for Hypothesis 3 - that the more states experience the increasing power gap difference with existing PTAs, the less likely states will maintain or develop those PTAs.

\section{Figure 3. Distributive PTA and Predicted Probabilities of PTA in Different Levels with $95 \%$ Confidence Bounds (from Model 5)}
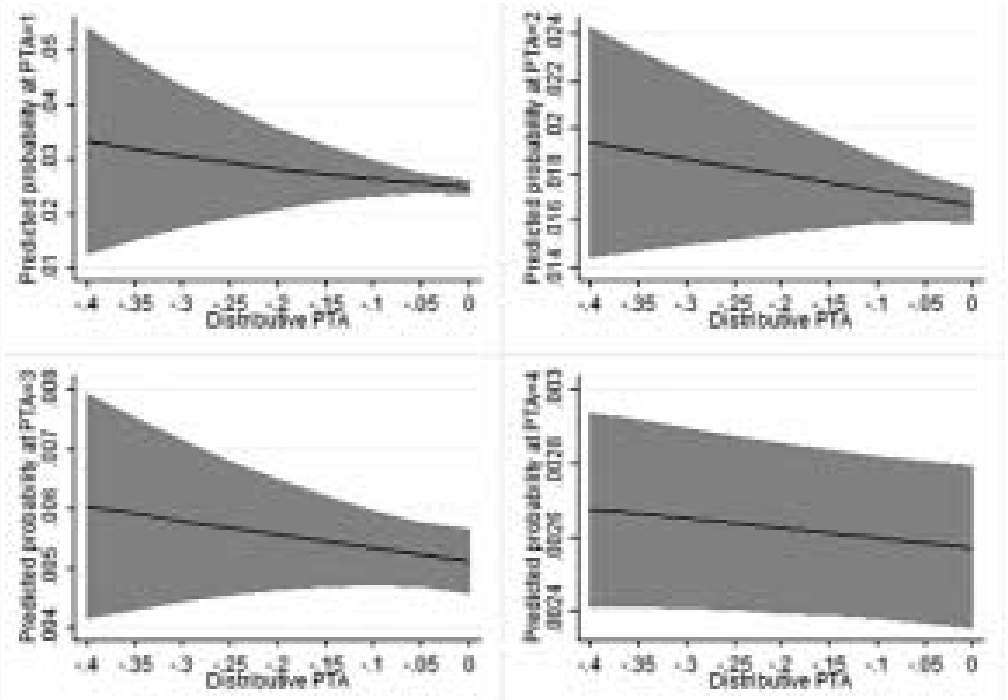

18 There are alternative model specifications in order to capture the data points on the left side of the parabola. For instance, Heckman's selection model (Heckman 1979) or a regression model upon subset samples on the left side would undertake similar analyses. The way in which the present study conducts the analyses, however, is different from ones these alternative specifications would do, in that these alternative specifications would draw straight lines rather than a curved one as the squared term in the present study does.

${ }^{19}$ As part of a model-selection strategy, it is acceptable to generate and include only this interaction term instead of including all simple and lower-order interaction terms, given certain circumstances. Such conditions are met when a researcher has prior knowledge, such as a theory, that allows the researcher to consider the possible existence of special points on the scales of explanatory variables, as is the case for this study (Nelder 1998). 


\section{DISCUSSION}

When would states be incentivized to establish institutionalized arrangements of formal economic integration? Under what conditions would states develop or degrade an existing agreement of formal economic integration? This study argues that changes in economic power gap differences motivate states to set their national interests toward pursuing PTAs and, therefore, examines the effects of changing economic power gap differences between states with large- $\mathrm{N}$ data. To be sure, the economic power gap difference is not the only reason, and there are other contexts in which states pursue PTAs. ${ }^{20}$ This section discusses the central argument with the contexts.

The Treaty of Rome, established on 1 January 1958, included among other things the formation of the European Economic Community (EEC), later known as the European Community (EC), ${ }^{21}$ which comprised six countries: Germany, France, Italy, Belgium, The Netherlands, and Luxemburg. Born under the looming threat of the Soviet Union and with the auspice of the United States, the EEC initially functioned as a customs union. This agreement of formal economic integration envisaged larger economies of scale, greater efficiency, and thus growthall resulting from the free movement of goods, services, capital, and labor. Such economic integration would be aided by common policies in agriculture, transportation, regional development, external commerce, research and development, economic cohesion, education, the environment, and other domains. In practice, the EC strongly took into consideration the distributive effects of economic integration as represented by multilateral development banks, structural funds for equitable development, and the Common Agricultural Policy (Griffith-Jones, Steinherr and Fuzzo de Lima 2006). These (re)distributive mechanisms, which functioned essentially as side-payments, further aided economic integration by compensating members that incurred costs as a result of further economic liberalization.

Growing economic power gap differences were significant reasons for subsequent EC enlargements. In reaction to the formation of the EC, in 1960 the United Kingdom, Austria, Denmark, Portugal, Norway, Sweden, and Switzerland established the European Free Trade Association (EFTA). Setting up this rival organi-

${ }^{20}$ I present multiple European cases at distinctive points in time because these points indicate different levels of economic integration, and thus fit for illuminating the proposed causes for developing further integration. The selection of European cases, however, does not imply that countries in other regions will follow the same path as Europe.

${ }^{21}$ I utilize the EC instead of the EU in order to avoid confusion with the concept of economic union used in the above statistical analyses. 
zation, these member states committed themselves to a minimalist integrative program; that is, a free trade area for industrial goods only. Foreign investors were understandably more attracted to the EC than to the EFTA because the former promised more benefits with its larger and better-integrated market than the latter with its less-integrated economy. As a result, more of the growth in total investments in the EC stemmed from this diversion of foreign investments from the nonEC countries of Western Europe to members of the EC (Yannopoulos 1990). This diversion, therefore, contributed to the worsening economic conditions of the EFTA states and, during the 1960s and 1970s, led these countries to commence negotiations to join or to form an FTA with the EC (Swann 2000, 34-46).

The EC's gradual approach to integrating countries from Eastern Europe, especially after 1990, involved efforts to reduce the socio-economic gaps between Western members and potential Eastern and Central European members. The EC feared massive migration and socio-economic chaos that might stem from negative externalities originating in the periphery of the EC. Among the most important negative externalities were economic mismanagement, political instability, and social unrest in the former member states of the Soviet Union. EC member states therefore initiated the PHARE and the TACIS programs for Eastern European countries, through which they could be offered technical assistance and advice in such areas as food distribution, privatization, banking, civil service reform, education, environmental management and energy development (Kramer 1993). ${ }^{22}$ Furthermore, in 1991 the EC signed association agreements also called "Europe Agreements" and were considered to be equivalent to FTAs with Czechoslovakia, Hungary, and Poland, for example, in exchange for their commitment to market economy reforms and pluralist democracy. Even before signing association agreements, the EC forged cooperation agreements with some countries as preparations for association agreements and, later, more extensive and inclusive agreements. It was evident that the countries in Eastern Europe wanted to catch up with Western Europe and thus preferred to join the $\mathrm{EC}$, as formal economic integration seemed to promise them economic development and a path to independence from the Soviet Union. As their situations improved, the EC offered Eastern Europe countries more formal political ties and greater market access by way of allowing for increased economic integration with the economies of Western Europe.

\footnotetext{
22 The PHARE programme, created in 1989, was originally the "Poland and Hungary: Assistance for Restructuring their Economies" programme, while the TACIS programme stood for "Technical Assistance to the Commonwealth of Independent States" programme designed to aid countries of the former Soviet Union.
} 


\section{CONCLUSION}

Preferential trade agreements (PTAs) have rapidly proliferated, especially since 1990. All PTAs are not the same, however, but vary according to their level and scope, indicating the differing depths of international cooperation. Why do certain groups of states experience economic integration - and some states very deep levels of integration - whereas others do not experience any? What determines the level of economic integration once the process is initiated? Although scholars have identified economic issues (e.g., economic size, development, or ideology), political regimes (e.g., democratic, autocratic, transitional), cultural conditions (e.g., ethnicity, language, colonial history), or security concerns (e.g., militarized conflicts, territorial disputes, military alliances) at various levels as causes for the establishment of PTAs, I have argued in this article that the discussion of economic power has largely been overlooked in the empirical literature. In particular, I have shown that the dynamics of power gap differences is a significant factor providing states with incentives to form, join, and/or develop PTAs. My argument, which has focused on the significance of the dynamics of power gap differences rather than on the effects of static power distributions, is a first among empirical studies on PTAs.

Focusing on market size as an expression of economic power, I have argued that there may be two different mechanisms involved in states pursuing PTAs. Incentives for states to sign PTAs will arise under the conditions that the countries are experiencing either an increasing or a decreasing economic power gap. An economically smaller state will want to catch up with an economically larger state by signing a PTA in order to link institutionally to, and benefit from, the relatively larger market. In order to receive positive effects that will emerge beyond economic issues, the stronger state will also agree to join PTAs, even though smaller states may be achieving both an absolute and a relative gain on their stronger cooperative partners.

Based on the proposed theory, I have tested hypotheses that the macro-structural conditions of both increasing and decreasing power gap differences are more likely to lead states to higher-level agreements of formal economic integration. One more condition was added to the analysis to test the likelihood of PTAs forming among states that experience decreasing economic power gap differences due to a previous agreement of formal economic integration. I conducted two analyses for the above three hypotheses. The first analysis included the squared term for the first two hypotheses. The second analysis generated a new conditional variable and ran the models with the new variable. Based on my original PTA data set, the ordered probit models largely supported the hypotheses 
and the predicted probabilities at each PTA level were plotted and discussed.

The arguments and the findings in this article have important implications for the literature on PTAs and present numerous avenues for future research. The findings highlight a mechanism for PTA development that scholars previously have not discussed to any great extent. In particular, this study has examined the effect of the presence of preexisting PTAs on later PTA development among the groups that experience decreasing power gap differences and how the distributive mechanism of preexisting PTAs can change the preferences of states for deeper and more extensive PTAs. Although only the effect of preexisting PTAs was investigated in this study, future research may tap into other preexisting ties as indications of interdependence to see whether such ties would contribute to the deepening of formal economic integration.

This research has also generated broader implications with respect to the conditions that lead to deepening formal economic integration. This study pushes our understanding of the impact of power distributions on international cooperation a step forward. It is not only the static power parity or disparity but also the dynamic changes in power distributions that affect the decision of states regarding what level of economic integration to pursue. The existing literature also suggests that the relative stability of states' capabilities will be more conducive to the establishment and development of institutionalized arrangements of formal economic integration than the relative disparity shift over time because states experiencing a negative power shift will oppose such development, fearing the solidification of a new status quo in which they are at a relative disadvantage (Grieco 1997). This study, however, did not assume the "willingness" of disadvantaged states to be dissatisfied, but rather, a state's attitude to be conditional based on the nature of preexisting interdependence regardless of their evolving status (Most and Starr 1989). The policy implications of this research are obvious for the relationship between the United States and China, as well as between Japan and China, all of them currently experiencing changing power gaps while competing with different plans for formal regional economic integration among themselves.

\section{REFERENCES}

Andrianmananjara, Soamiely. 2002. "On The Size and Number of Preferential Trading Arrangements.” Journal of International Trade \& Economic Development 11(3), 279-295.

Axelrod, Robert and Robert Keohane. 1985. "Achieving Cooperation Under Anarchy: Strategies and Institutions.” World Politics 38(1), 226-254. 
Baccini, Leonardo and Johannes Urpelainen. 2012. "Strategic Side Payments: Preferential Trading Agreements, Economic Reform, and Foreign Aid.” Journal of Politics 74(4), 932-949.

Balassa, Bela. 1961. The Theory of Economic Integration. Homewood, IL: Richard D. Irwin, INC.

Baldwin, Richard and Dany Jaimovich. 2012. "Are Free Trade Agreements Contagious?” Journal of International Economics 88, 1-16.

Bearce, David and Stacy Bondanella. 2007. "Intergovernmental Organizations, Socialization, and Member-State Interest Convergence.” International Organization 61(4), 703-733.

Beck, Nathaniel, Jonathan Katz and Richard Tucker. 1998. "Taking Time Seriously: Time-Series - Cross-Section Analysis with a Binary Dependent Variable." American Journal of Political Science 42(4), 1260-1288.

Bueno de Mesquita, Bruce, Alastair Smith, Randolph M. Siverson and James D. Morrow. 2005. The Logic of Political Survival. Cambridge, Mass.: The MIT Press.

Büthe, Tim and Helen V. Milner. 2014. "Foreign Direct Investment and Institutional Diversity in Trade Agreements: Credibility, Commitment, and Economic Flows in the Developing World, 1971-2007." World Politics 66(1), 88-122.

Cao, Xun. 2009. "Networks of Intergovernmental Organizations and Convergence in Domestic Economic Policies." International Studies Quarterly 53(4), 1095-1130.

Caporaso, James A. and Stephan Haggard. 1989. "Power in the International Political Economy.” In Richard J. Stoll and Michael D. Ward eds., Power in World Politics, Boulder, CO: Lynne Rienner Publishers, 99-120.

Carter, David B. and Curtis S. Signorino. 2010. "Back to the Future: Modeling Time Dependence in Binary Data." Political Analysis 18, 271-292.

Cheibub, José Antonio, Jennifer Gandhi and James Raymond Vreeland. 2010. "Democracy and Dictatorship Revisited." Public Choice 143(1-2), 67-101.

Crone, Donald. 1993. "Does Hegemony Matter? The Reorganization of the Pacific Political Economy." World Politics 45(4), 501-525.

De Melo, Jaime and Arvind Panagariya, eds. 1995. New Dimensions in Regional Integration. New York, NY: Cambridge University Press.

Deutsch, Karl W., Sidney A. Burrell, Robert A. Kann, Jr., Maurice Lee, Martin Lichterman, Raymond E. Lindgren, Francis L. Loewenheim and Richard W. Van Wagenen. 1957. Political Community and the North Atlantic Area: International Organization in the Light of Historical Experience. New York: Greenwood Press. 
Dixon, William J. 1993. "Democracy and the Management of International Conflict.” Journal of Conflict Resolution 37(1), 42-68.

Feenstra, Robert C., Robert Inklaar and Marcel P. Timmer. 2013. "The Next Generation of the Penn World Table." available for download at www.ggdc.net/pwt.

Finn, Laursen, ed. 2010. Comparative Regional Integration: Europe and Beyond. Burlington, VT: Ashgate Publishing Company.

Fiorentino, Robert V., Luis Verdeja and Christelle Toqueboeuf. 2006. "The Changing Landscape of Regional Trade Agreements: 2006 Update." 12, Geneva, Switzerland: World Trade Organization.

Franzese, Robert J. Jr. and Jude C. Hays. 2007. "Spatial Econometric Models of Cross-Section Interdependence in Political Science Panel and TimeSeries-Cross-Section Data." Political Analysis 15, 140-164.

Genna, Gaspare M. and Taeko Hiroi. 2004. "Power Preponderance and Domestic Politics: Explaining Regional Economic Integration in Latin America and the Caribbean." International Interactions: Empirical and Theoretical Research in International Relations 30(2), 143-164.

Ghosn, Faten and Scott Bennett. 2003. "Codebook for the Dyadic Militarized Interstate Incident Data. Version 3.10." available for download at http://correlatesofwar.org.

Grieco, Joseph M. 1997. "Systemic Sources of Variation in Regional Institutionalization in Western Europe, East Asia, and the Americas". In Edward D. Mansfield and Helen V. Milner eds., The Political Economy of Regionalism. New York: Columbia University Press, 164-187.

. 1999. "Realism and Regionalism: American Power and German and Japanese Institutional Strategies During and After the Cold War." In Ethan B. Kapstein and Michael Mastanduno eds., Unipolar Politics: Realism and State Strategy after the Cold War, New York: Columbia University Press, 319-353.

Griffith-Jones, Stephany, Alfred Steinherr and Ana Teresa Fuzzo de Lima. 2006. "European Financial Institutions: A Useful Inspiration for Developing Countries?” In Jose Antonio Ocampo ed., Regional Financial Cooperation. Washington, DC: Brookings Institution Press and Economic Commission For Latin America Caribbean, 136-163.

Grossman, Gene M. and Alan B. Krueger. 1993. "Environmental Impact of a North American Free Trade." In Peter M. Garger ed., The Mexico-U.S. Free Trade Agreement. Cambridge, MA: MIT Press, 13-56.

Grossman, Gene M. and Elhanan Helpman. 1995. "The Politics of Free-Trade Agreements." American Economic Review 85(4), 667-690. 
Hafner-Burton, Emilie M. 2005. "Trading Human Rights: How Preferential Trade Agreements Influence Government Repression.” International Organization 59(3), 593-629.

Hausman, J. A. 1978. "Specification Tests in Econometrics.” Econometrica 46(6), 1251-1271.

Heckman, James J. 1979. "Sample Selection Bias as a Specification Error." Econometrica 47(1), 153-162.

Hegre, Harvard, John R. Oneal and Bruce Russett. 2010. “Trade Does Promote Peace: New Simultaneous Estimates of the Reciprocal Effects of Trade and Conflict." Journal of Peace Research 47(6), 763-774.

Ikenberry, G. John. 2001. After Victory: Institutions, Strategic Restraint, and the Rebuilding of Order after Major Wars. Princeton, NJ: Princeton University Press.

Jinnah, Sikina. 2011. "Strategic Linkages: The Evolving Role of Trade Agreements in Global Environmental Governance." Journal of Environment \& Development 20(2), 191-215.

Kang, David C. 2009. "Between Balancing and Bandwagoning: South Korea's Response to China." Journal of East Asian Studies 9, 1-28

Kim, Moonhawk. 2012. "Ex Ante Due Diligence: Formation of PTAs and Protection of Labor Rights." International Studies Quarterly 56(4), 704719.

Kim, Woosang and James D. Morrow. 1992. "When Do Power Shift Lead to War?” American Journal of Political Science 36(4), 896-922.

Kono, Daniel Y. 2007. 'Who Liberalizes? Explaining Preferential Trade Liberalization.” International Interactions: Empirical and Theoretical Research in International Relations 33(4), 401-421.

Koremenos, Barbara, Charles Lipson and Duncan Snidal. 2001. "The Rational Design of International Institutions." International Organization 55(4), 661-699.

Kramer, Heinz. 1993. "The European Community's Response to the 'New Eastern Europe'.” Journal of Common Market Studies 31(2), 213-244.

Krasner, Stephen. 1976. "State Power and the Structure of International Trade." World Politics 28(3), 317-347.

Lee, Taedong and Byoung-Inn Bai. 2013. "Network Analysis of Free Trade Agreements: Homophily and Transitivity." The Korean Journal of International Studies 11(2), 263-293.

Lemke, Douglas. 2002. Regions of War and Peace. Cambridge, England: Cambridge University Press.

Mansfield, Edward D. 1994. Power, Trade, and War. Princeton, NJ: Princeton 
University Press.

Mansfield, Edward D. and Eric Reinhardt. 2008. "International Institutions and the Volatility of International Trade.” International Organization 62(4), 621-652.

Mansfield, Edward D. and Helen V. Milner. 1999. "The New Wave of Regionalism." International Organization 53(3), 589-627. . 2012. Votes, Vetoes, and the Political Economy of International Trade Agreements. Princeton, NJ: Princeton University Press.

Mansfield, Edward D., Helen V. Milner and Jon C. Pevehouse. 2007."Vetoing Cooperation: The Impact of Veto Players on Preferential Trading Arrangements." British Journal of Political Science 37, 403-432. . 2008. "Democracy, Veto Players and the Depth of Regional Integration." The World Economy 31(1), 67-96.

Mansfield, Edward D. and Jon C. Pevehouse. 2000. "Trade Blocs, Trade Flows and International Conflict." International Organization 54(4), 775-808.

Mansfield, Edward D., Jon C. Pevehouse and David H. Bearce. 1999. "Preferential Trading Arrangements and Military Disputes." Security Studies 9(12), 92-118.

Marshall, Monty G. and Keith Jaggers. 2009. Polity IV Project: Dataset Users' Manual. Vienna, VA: Center for Systemic Peace.

Mattli, Walter. 1999. The Logic of Regional Integration: Europe and Beyond. New York, NY: Cambridge University Press.

Merritt, Richard L. and Dina A. Zinnes. 1989. "Alternative Indexes of National Power." In Richard J. Stoll and Michael D. Ward eds., Power in World Politics. Boulder, CO: Lynne Rienner Publishers, 11-28.

Milner, Helen V. and Keiko Kubota. 2005. "Why the Move to Free Trade? Democracy and Trade Policy in the Developing Countries." International Organization 59(1), 107-143.

Moravcsik, Andrew. 1997. "Taking Preferences Seriously: A Liberal Theory of International Politics." International Organization 51(4), 513-553.

Morgan, Clifton T. and Glenn Palmer. 2000. "A Model of Foreign Policy Substitutability: Selecting the Right Tools for the Job(s)." Journal of Conflict Resolution 44(1), 11-32.

Morrow, James. 1999. "The Strategic Setting of Choices: Signaling, Commitment, and Negotiation in International Politics." In David Lake and Robert Powell eds., Strategic Choice and International Relations, Princeton, NJ: Princeton University Press, 77-114.

Morrow, James D. 1991. "Alliances and Asymmetry: An Alternative to the Capability Aggregation Model of Alliances." American Journal of 
Political Science 35(4), 904-933.

Most, Benjamin A. and Harvey Starr. 1989. Inquiry, Logic, and International Politics. Columbia, SC: University of South Carolina Press.

Myrdal, Gunnar. 1957. Economic Theory and Underdeveloped Regions. London: Gerald Duckworth \& Co.

Nelder, John A. 1998. "The Selection of Terms in Response-Surface ModelsHow Strong is the Weak-Heredity Principle?” The American Statistician 52(4), 315-318.

Neumayer, Eric and Thomas Plümper. 2010. "Spatial Effects in Dyadic Data." International Organization 64(1), 145-166.

North, Douglass C. 1991. "Institutions." The Journal of Economic Perspectives 5(1), 97-112.

Nye, Joseph S. 1971. Peace in Parts: Integration and Conflict in Regional Organization. Boston, MA: Little and Brown.

Pevehouse, Jon C., Timothy Nordstrom, and Kevin Warnke. 2004. "The COW-2 International Organizations Dataset Version 2.o." Conflict Management and Peace Science 21(2), 101-119.

Pollins, Brian M. 1989. "Conflict, Cooperation, and Commerce: The Effect of International Political Interactions on Bilateral Trade Flows." American Journal of Political Science 33(3), 737-761.

Powell, Robert. 1991. "Absolute and Relative Gains in International Relations Theory." The American Political Science Review 85(4), 1303-1320.

Przeworski, Adam. 1991. Democracy and the Market: Political and Economic Reform in Eastern Europe and Latin America. New York: Cambridge University Press.

Putnam, Robert D. 1988. "Diplomacy and Domestic Politics: The Logic of TwoLevel Games." International Organization 42(3), 427-460.

Russett, Bruce M. 1974. Power and Community in World Politics. New York, NY: W. H. Freeman.

Simmons, Beth A., Frank Dobbin and Geoffrey Garrett. 2006. 'Introduction: The International Diffusion of Liberalism.” International Organization 60(4), 781-810.

Simmons, Beth A. and Zachary Elkins. 2004. "The Globalization of Liberalization: Policy Diffusion in the International Political Economy." American Political Science Review 98(1), 171-189.

Snidal, Duncan. 1985. “The Limits of Hegemonic Stability Theory.” International Organization 39(4), 579-614.

Solingen, Etel. 1998. Regional Orders at Century's Dawn: Global and Domestic Influences on Grand Strategy. Princeton, NJ: Princeton University Press. 
Solís, Mireya, Barbara Stallings and Saori N. Katada, eds. 2009. Competitive Regionalism: FTA Diffusion in the Pacific Rim. New York: Palgrave Macmillan.

Stein, Arthur, A. 2003. "Trade and Conflict: Uncertainty, Strategic Signaling, and Interstate Disputes." In Edward D. Mansfield and Brian M. Pollins eds., Economic Interdependence and International Conflict: New Perspectives on an Enduring Debate, Ann Arbor, MI: The University of Michigan Press, 111-126.

Stone Sweet, Alec and Wayne Sandholtz. 1997. "European Integration and Supranational Governance.” Journal of European Public Policy 4(3), 297-317.

Swann, Dennis. 2000. The Economics of the Common Market. New York: Penguin Books.

Tsebelis, George. 1990. Nested Games: Rational Choice in Comparative Politics. Berkeley and Los Angeles, CA: University of California Press.

Viner, Jacob. 1948. "Power versus Plenty as Objectives of Foreign Policy in the Seventeen and Eighteenth Centuries.” World Politics 1(1), 1-29.

Wallace, William. 1994. Regional Integration: The West European Experience. Washington, D.C.: The Brookings Institution.

Yannopoulos, George N. 1990. "Foreign Direct Investment and European Integration: The Evidence from the Formative Years of the European Community." Journal of Common Market Studies 28(3), 235-259. 